\title{
Keterampilan Literasi Sains Peserta Didik dengan Model Pembelajaran Reading, Questioning, and Answering (RQA) dalam Pembelajaran Biologi
}

\author{
Fitri Hidayahtika $^{1)}$, Purwati Kuswarini Suprapto ${ }^{2)}$, Diana Hernawati ${ }^{3)}$ \\ 123 Jurusan Pendidikan Biologi, Fakultas Keguruan dan Ilmu Pendidikan, Universitas Siliwangi \\ E-mail: fitrihidayahtika@gmail.com \\ E-mail: purwatikuswarini@unsil.ac.id \\ E-mail: hernawatibiologi@unsil.ac.id
}

APA Citation: Hidayantika, F., Suprapto, P. K., \& Hernawati, D. (2020). Keterampilan Literasi Sains Peserta Didik dengan Model Pembelajaran Reading, Questioning, and Answering (RQA) dalam Pembelajaran Biologi. Quagga: Jurnal Pendidikan dan Biologi, 12(1), 69-75. doi: 10.25134/quagga.v12i1.2123.

Received: 05-11-2019

Accepted: 27-01-2020

Published: 30-01-2020

\begin{abstract}
Abstrak : Keterampilan literasi sains tetap menjadi tantangan utama untuk ditingkatkan melalui model pembelajaran yang aktif. Model pembelajaran RQA (reading, questioning, and answering) merupakan model pembelajaran aktif yang menekankan pada kegiatan membaca, bertanya, dan menjawab pertanyaan yang diharapkan akan mampu meningkatkan keterampilan literasi sains. Penelitian ini bertujuan untuk mengetahui adanya pengaruh model RQA terhadap peningkatakan keterampilan literasi sains peserta didik pada materi sel. Penelitian eksperimen semu ini menggunakan model rancangan penelitian nonequivalent control group design. Penelitian dilakukan di salah satu SMAN di Kota Tasikmalaya yang merupakan sekolah rujukan Gerakan Literasi Sekolah (GLS) tahun ajaran 2018/2019. Variabel bebas pada penelitian ini yaitu Model RQA dan variabel terikat yaitu keterampilan literasi sains peserta didik. Populasi seluruh kelas XI MIPA tahun ajaran 2019/2020. Sampel penelitian menggunakan teknik purposive sampling berdasarkan data minat baca dari GLS, sehingga dapat ditentukan dua kelas sebagai kelas penelitian dengan perlakuan eksperimen dan kontrol. Teknik pengumpulan data menggunakan instrumen tes keterampilan literasi sains. Data dianalisis dengan menggunakan Uji t dua sampel independent, menyatakan $t_{\text {hitung }}>t_{\text {tabel }}$ yaitu 3,985 > 1,997, menyimpulkan terdapat pengaruh peningkatan keterampilan literasi sains dengan menggunakan model RQA.
\end{abstract}

Kata Kunci: keterampilan literasi sains; peserta didik; RQA.

\begin{abstract}
Scientific literacy skills remain a major challenge to be improved through active learning models. Reading, Questioning, and Answering (RQA) learning models is an active learning model that emphasizes reading, asking and answering questions that expected to be able to improve scientific literacy skills. This study aims to determine the effect of the RQA model on improving student's scientific literacy skills on cell theory. This quasi-experimental research used the nonequivalent control group design reseach model. Research was carried out at one of the SMAN in Tasikmalaya city which is the School Literacy Programs reference (SLP) school in 2018/2019. The independent variable in this study is the RQA model and the dependent variable is the scientific literacy skills of student. The whole population are class of XI MathScience in this year 2019/2020. The research sample used purposive sampling technique based on reading interest data from SLP, so that two classes can be determined as a research class with experimental and control treatments. Data collection techniques used the instrument of scientific literacy skills test. Data were analyzed by using $t$ Test two independent sample, stated $t_{\text {count }}>t_{\text {table }}$ that's 3,985 $>1,997$, it concluded there was an influence improved of scientific literacy skills using the RQA model.
\end{abstract}

Keywords: RQA; scientific literacy skills; students.

\section{PENDAHULUAN}

Perkembangan abad 21 menghasilkan perubahan pesat di dalam bidang Ilmu, Pengetahuan, Teknologi, dan Sains (IPTEKS).
Perubahan tersebut sering kali disertakan dengan permasalahan-permasalahan baru yang terkait etika, moral, dan isu-isu global yang justru dapat mengancam martabat dan 
Quagga: Jurnal Pendidikan dan Biologi

Volume 12, Nomor 1, Januari 2020, pp.69-75
p-ISSN 1907-3089, e-ISSN2651-5869

https://doi.org/10.25134/quagga.v12i1.2123 kelangsungan hidup manusia (Yaumi, Wisanti, \& Admoko, 2017: 38). Pendidikan abad 21 mampu memberikan solusi untuk memecahkan permasalahan-permasalahan tersebut, salah satunya dengan memberikan bekal keterampilan abad 21 pada generasi penerus. Liu (2009: 301) menyatakan bahwa, salah satu keterampilan yang diperlukan pada abad 21 adalah literasi sains.

Keterampilan literasi sains penting dimiliki oleh peserta didik Indonesia. Namun, fakta membuktikan hasil capaian literasi sains peserta didik Indonesia masih tergolong rendah. Data Program for International Student Assessment (PISA) menunjukkan skor dan peringkat literasi sains yang dicapai peserta didik Indonesia dari tahun 2009, 2012, dan 2015 berturut-turut sebesar 383, 382, dan 402 dengan rata-rata skor OECD 501 di tahun 2009-2012 dan 493 pada tahun 2015, serta peringkatnya berturut-turut 57 dari 65 negara, 64 dari 65 negara, dan 62 dari 70 negara (OECD, 2012). Rendahnya rata-rata literasi sains pada PISA tersebut, membuktikan bahwa banyak peserta didik di Indonesia tidak mampu mengaitkan pengetahuan sains yang dipelajarinya dengan fenomena-fenomena yang terjadi di lingkungan sekitarnya. Hal tersebut terjadi karena rendahnya kemampuan membaca dan memaknai bacaan, serta pembelajaran sains yang terjadi di Indonesia belum memberikan penekanan pada penerapan dalam dunia nyata.

Berdasarkan hasil observasi dan wawancara Guru Biologi di salah satu sekolah di Kota Tasikmalaya yang menjadi rujukan Gerakan Literasi Sekolah (GLS), menyatakan bahwa keterampilan literasi sains dan literasi membaca peserta didik selama pembelajaran biologi masih terbilang rendah. Rendahnya keterampilan literasi sains peserta didik dapat dilihat berdasarkan kemampuan peserta didik yang hanya mampu dalam mengidentifikasi beberapa permasalahan dalam kehidupan sehari-hari terkait proses pembelajaran. Rendanya keterampilan literasi sains juga dipengaruhi oleh rendahnya minat baca dan kemampuan membaca sains peserta didik. Permasalahan tersebut terjadi karena kemampuan guru yang belum mampu menerapkan model pembelajaran yang mampu meningkatkan keterampilan literasi sains dan literasi membaca peserta didik.

Salah satu materi yang dipandang penting untuk mengukur keterampilan literasi sains adalah sel. Materi sel merupakan materi yang terbilang rumit, karena peserta didik harus mampu memahami fenomena kehidupan yang berhubungan dengan struktur, fungsi dan keterkaitan antara keduanya (Saptono, et al., 2013: 32). Serta pada materi sel terdapat banyak istilah-istilah biologi yang perlu dipahami, sehingga keterampilan literasi sains sangat diperlukan untuk membantu peserta didik dalam memahami materi tersebut.

Berdasarkan permasalahan di atas, maka kemampuan literasi sains perlu dimiliki oleh peserta didik sesuai dengan tuntutan keterampilan abad 21. Holbrook \& Rannikmae (2009: 278) memandang literasi sains sebagai sebuah syarat yang harus dimiliki peserta didik dalam menyesuaikan tantangan perubahan zaman yang cepat sehingga dalam pembelajaran literasi sains dipraktikan secara beriringan dengan pengembangan life skills. Program for International Student Assessment (PISA) menggambarkan literasi sains sebagai kemampuan menggunakan pengetahuan sains, mengidentifikasi permasalahan, menarik kesimpulan berdasarkan bukti-bukti, dan akhirnya membuat sebuah keputusan yang tepat (Gormally, Brickman, \& Lut, 2012: 364). Pentingnya kemampuan literasi sains tersebut harus dipersiapkan pada generasi muda agar dapat menyelesaikan permasalahan pada kehidupannya.

Keterampilan literasi sains tetap menjadi tantangan utama untuk ditingkatkan melalui model pembelajaran yang aktif. Model pembelajaran yang dianggap dapat memenuhi kriteria komponen literasi sains adalah model pembelajaran reading questioning and answering (RQA). Model pembelajaran RQA merupakan suatu model pembelajaran yang berlandaskan pada teori pembelajaran konstruktivisme (Haerullah, 2013: 181). Model ini berpusat pada peserta didik dengan memberikan kesempatan dalam mengkonstruksi pengetahuannya sendiri, sesuai dengan tuntutan kurikulum 2013. Di dalam kegiatan pembelajarannya, model ini meminta 
Quagga: Jurnal Pendidikan dan Biologi

Volume 12, Nomor 1, Januari 2020, pp.69-75
p-ISSN 1907-3089, e-ISSN2651-5869

https://doi.org/10.25134/quagga.v12i1.2123 peserta didik untuk aktif membaca materi dan menjadikan peserta didik aktif untuk bertanya mengenai materi yang belum diketahui.

Kegiatan membaca, bertanya dan menjawab dalam model pembelajaran RQA, diharapkan akan mampu meningkatkan keterampilan literasi sains. Sebagaimana dikatakan, melalui kebiasaan membaca, seseorang dapat terlatih untuk memilah-milah informasi yang otentik, melatih kemampuan berpikir kritis, dan mengembangkan kecakapan khususnya kemampuan analisis (Bahri, 2016: 112). Kemampuan membaca merupakan faktor yang berpengaruh terhadap kemampuan peserta didik untuk memperoleh dan memahami informasi dari artikel dan bahan bacaan sains serta dapat melakukan analisis dan evaluasi isi bacaan tersebut berdasarkan pengalaman dan pengetahuan yang telah dimiliki peserta didik.

Model RQA merupakan solusi dalam memahami materi sel yang terbilang rumit. Hal tersebut dikarenakan, penggunaan model RQA dapat meningkatkan kemampuan berpikir peserta didik (Mulyadi, Adlim, \& Djufri, 2014: 37). Akmaliya \& Hapsari (2016: 78) menyebutkan, implementasi model pembelajaran RQA yang mengajak peserta didik menemukan ide pokok sebelum melanjutkan pembelajarannya, diharapkan memudahkan peserta didik dalam memahami materi sel. Maka, penggunaan model pembelajaran RQA diharapkan akan memberikan pengaruh dalam peningkatan literasi sains peserta didik pada materi sel.

\section{METODOLOGI PENELITIAN}

Metode penelitian yang digunakan dalam penelitian ini adalah metode quasi experimental design dengan rancangan penelitian nonequivalent control group design. Penelitian ini terdiri dari kelompok eksperimen yaitu kelas yang diberi perlakuan menggunakan model RQA sedangkan kelompok kontrol yaitu kelas yang menggunakan model pembelajaran langsung. Populasi penelitian terdiri dari seluruh peserta didik kelas XI MIPA di salah satu SMAN di Kota Tasikmalaya pada semester gasal tahun ajaran 2019/2020. Pengambilan sampel dipilih secara purposive berdasarkan pada hasil data GLS tahun ajaran 2018/2019, sehingga didapati kelas eksperimen dan kelas kontrol masing-masing terdiri dari 35 orang peserta didik.

Pengumpulan data dalam penelitian ini menggunakan tes literasi sains yang mengacu pada TOSLS yang dikembangkan oleh (Gormally et al., 2012). Tes literasi sains yang digunakan terdiri dari 22 soal pilihan ganda yang memuat empat skill literasi sains (Tabel 1). Tes yang diberikan sudah divalidasi oleh ahli dan diujicobakan kepada peserta didik kelas XII.

Data yang diambil dari penelitian ini meliputi pretest dan posttest yang dilakukan di kelas kontrol dan eksperimen yang dianalisis peningkatannya dengan menggunakan $\mathrm{N}$-gain Sedangkan uji hipotesis dilakukan dengan uji t.

Tabel 1. Instrumen Literasi Sains

\begin{tabular}{lrc}
\hline \multicolumn{2}{c}{ Skill Literasi Sains } & $\begin{array}{c}\text { Nomor Butir } \\
\text { Soal }\end{array}$ \\
\hline \hline $\begin{array}{l}\text { Mengidentifikasi } \\
\text { saintifik yang valid }\end{array}$ & argumen & $\begin{array}{c}2,13,15,26, \\
38\end{array}$ \\
\hline $\begin{array}{l}\text { Mengevaluasi kevalidan dari } \\
\text { suatu sumber }\end{array}$ & $5,18,30,40$, \\
$\begin{array}{l}\text { Mengevaluasi penggunaan dan } \\
\text { penyalahgunaan }\end{array}$ & $7,19,44,45$ \\
saintifik & informasi & \\
$\begin{array}{l}\text { Memahami elemen desain } \\
\text { penelitian dan bagaimana } \\
\text { dampaknya terhadap penemuan } \\
\text { saintifik }\end{array}$ & $36,46,47,48$ \\
\hline
\end{tabular}

\section{HASIL DAN PEMBAHASAN}

Data yang diperoleh dari pretest dan posttest setalah dilakukan uji prasyarat menunjukkan data yang normal dan homogen. Maka, dilanjutkan dengan uji t dua sampel independent dengan hasil analisis $t_{\text {hitung }}>t_{\text {tabel }}$ yaitu 3,985 > 1,997 dengan kesimpulan Tolak $\mathrm{H}_{0} \quad$ yang artinya ada pengaruh model pembelajaran RQA (Reading, Questioning, and Answering) terhadap keterampilan literasi sains peserta didik pada materi sel.

Adapun bukti lain yang membuktikan bahwa keterampilan literasi sains peserta didik lebih baik di kelas eksperimen daripada kelas kontrol, dapat dilihat berdasarkan rata-rata skor pretest, posttest, dan skor $N$-gain (Gambar 1). 
Quagga: Jurnal Pendidikan dan Biologi

Volume 12, Nomor 1, Januari 2020, pp.69-75

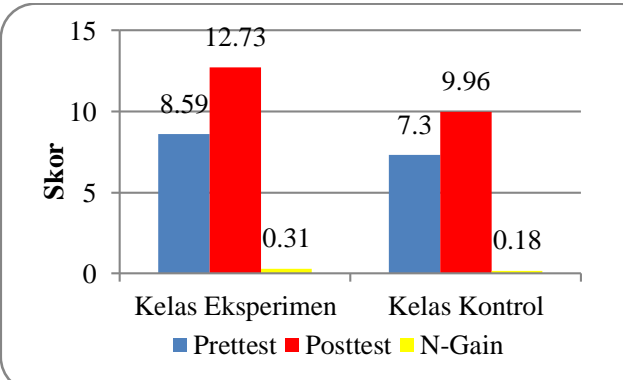

Gambar 1. Grafik Rata-rata Skor Pretest,

Posttest, dan $\mathrm{N}$-gain Keterampilan Literasi

Sains Kelas Eksperimen dan Kelas Kontrol

Gambar 1 menjelaskan skor rata-rata pretest, posttest, dan $\mathrm{N}$-gain keterampilan literasi sains kelas eksperimen dan kelas kontrol. Berdasarkan perolehan skor $N$-gain kelas eksperimen pada keterampilan literasi sains yaitu 0,31 dengan kriteria skor sedang. Sedangkan skor $\mathrm{N}$-gain kelas kontrol yaitu 0,18 dengan kriteria rendah.

Perbedaan jelas terlihat dari keterampilan literasi sains peserta didik yang menggunakan model RQA. Sebab model RQA merupakan model pembelajaran yang aktif. Maulida, Yusrizal, \& Melvina (2017: 85) bahkan menyatakan bahwa, "model RQA menggunakan pendekatan student centered". Hal ini berbeda dengan model pembelajaran DI yang berorientasi pada guru. Sehingga pada proses pembelajarannya, guru bertindak sebagai fasilitator yang membantu peserta didik dalam kegiatan belajarnya. Peserta didik melakukan penugasan di rumah yaitu membaca, merangkum, membuat pertanyaan dan menjawabnya secara mandiri, hal tersebut sesuai dengan penelitian yang dilakukan oleh Corebima, Hariyadi, \& Zubaidah (2018: 81). Penugasan yang dilakukan memberikan pengaruh pada peserta didik menjadi lebih aktif dalam proses pembelajaran (Sudin, Duda, \& Supiandi, 2018: 4). Terbukti dari peserta didik yang lebih aktif dalam proses pembelajaran, baik itu dalam bentuk bertanya, berdiskusi dan presentasi.

Model RQA memberikan pengaruh karena menuntut peserta didik untuk aktif dan mengkonstruksi pemikirannya dalam proses pembelajarannya, dengan melakukan kegiatan membaca, bertanya dan menjawab pertanyaan.
p-ISSN 1907-3089, e-ISSN2651-5869

https://doi.org/10.25134/quagga.v12i1.2123

Menggunakan model RQA juga dapat meningkatkan minat baca dan kemampuan membaca sains, hal tesebut terjadi karena menurut Mulyadi, Adlim, \& Djufri (2014: 34), "implementasi model pembelajaran RQA mampu mendorong para peserta didik untuk membaca materi pembelajaran yang ditugaskan".

Peningkatan minat baca dan kemampuan membaca sains peserta didik sangat berpengaruh terhadap kemampuan berpikir kritis peserta didik dikarenakan membaca merupakan proses yang aktif, dinamis yang dengan proses tersebut membantu peserta didik untuk menjadi pemikir kritis (Wakhidah, 2012: 73). Pencapaian tahap berpikir peserta didik menuju berpikir kritis dimulai dari rasa ingin tahu peserta didik. Tahap questioning dalam model RQA secara tidak langsung meningkatkan rasa ingin tahu peserta didik terhadap pembelajaran. Banyaknya pertanyaan yang diajukan mulai dari pertanyaan tingkat rendah sampai tingkat tinggi wujud dari rasa ingin tahu yang tinggi. Maka rasa ingin tahu yang tinggi dari peserta didik memengaruhi peningkatan keterampilan sains.

Tahap questioning dan answering dalam RQA memfasilitasi peserta didik untuk mengidentifikasi pertanyaan, mencari sumber jawaban pertanyaan, menjelaskan dan menarik kesimpulan akan menimbulkan sikap keilmiahan peserta didik. Kegiatan tersebut secara tidak langsung mengarahkan peserta didik untuk berpikir kritis. Hal ini selaras dengan pernyataan Purwanto (2018: 48) bahwa, "model RQA mampu meningkatkan keterampilan berpikir kritis". Pada prosesnya dapat terlihat ketika proses kegiatan answering peserta didik berdiskusi secara aktif, mencari jawaban di internet, kemudian mengklarifikasikannya dengan guru, untuk menentukan proses berpikir yang dilakukannya tersebut telah tepat. Sehingga model RQA mampu meningkatkan kemampuan berpikir tingkat tinggi peserta didik (Mulyadi et al., 2014: 37). Kemampuan tersebut seperti berpikir logis, kritis, beragumentasi secara benar, berkomunikasi dan berinteraksi, merupakan tujuan dari keterampilan literasi sains. Maka dengan menggunakan model RQA mampu 
meningkatkan keterampilan literasi sains peserta didik.

Perbedaan peningkatan keterampilan literasi sains pada kelas eksperimen dan kelas kontrol dapat dilihat dari perolehan skor $N$-gain tiap indikator dari hasil pretest dan posttest yang terdiri dari 22 soal yang tersebar dalam 4 skill. Hasil tersebut dapat dilihat pada diagram berikut ini (Gambar 2).

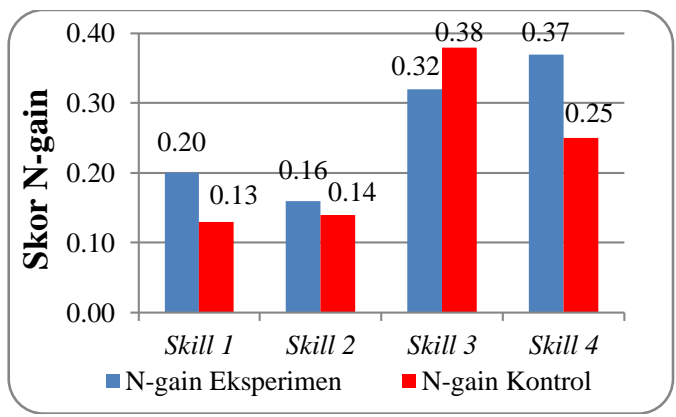

Gambar 2.Grafik $N$-gain Keterampilan Literasi Sains Kelas Eksperimen dan Kelas Kontrol

Berdasarkan gambar 2 menjelaskan skill 1 skor $N$-gain di kelas eksperimen 0,20 sedangkan di kelas kontrol 0,13 , kriteria $N$ gain-nya masih dalam kategori rendah. Sama halnya pada skill 2, kelas eksperimen 0,16 dan kelas kontrol 0,14, hanya berbeda sedikit. Seharusnya tahapan-tahapan pembelajaran dari model RQA mampu meningkatkan keterampilan literasi sains secara signifikan. Hal ini selaras dengan pernyataan Maknun (2014: 142) bahwa, "ketika peserta didik secara tidak langsung dipaksa untuk membaca sesuatu yang berhubungan dengan topik yang dibahas baik itu dari buku atau sumber manapun yang kredibel, maka peserta didik memiliki keterampilan literasi yang baik".

Pada skill 1 tidak mengalami peningkatan yang disignifikan pada kelas eksperimen, meskipun jika dibandingkan dengan kelas kontrol kelas eksperimen memiliki skor yang lebih tinggi. Skill 1 merupakan keterampilan yang menekankan pada area pengetahuan konten, yang merupakan soal-soal biasa yang mengukur kognitif. Jika dilihat dari prosesnya, pada skill 1 yang mengukur keterampilan argumen saintifik yang valid, terjadi karena pada saat kegiatan pembelajaran berlangsung peserta didik tidak diarahkan membaca materi secara keseluruhan. Kegiatan membaca pada peserta didik hanya menekankan pada sub-sub topik materi pembelajaran. Sehingga hal tersebut menyebabkan masih rendahnya peningkatan skor $N$-gain pada skill 1 . Pada kelas kontrol peningkatan yang tidak signifikan terjadi karena proses pembelajaran yang terjadi menekankan pada teacher centered yang hanya menggunakan metode ceramah.

Pada skill 2 yang mengukur keterampilan mengevaluasi kevalidan dari suatu sumber tidak mengalami peningkatan yang signifikan. Pada model RQA rendahnya skor $\mathrm{N}$-gain ini dipengaruhi oleh kegiatan membaca yang sumber bacaannya masih dibebaskan, sehingga peserta didik banyak mengambil sumber dari media internet yang menjadikan peserta didik kesulitan untuk menemukan sumber yang valid. Sedangkan pada kelas kontrol peserta didik tidak ditekankan kegiatan membaca dan hanya berfokus pada materi yang disampaikan oleh guru.

Sedangkan pada skill 3, yaitu yang mengukur keterampilan mengevalusi penggunaan dan penyalahgunaan informasi saintifik, skor $N$-gain di kelas kontrol lebih tinggi dibandingkan kelas eksperimen. Skor $N$ gain kelas eksperimen yaitu 0,32 , sedangkan kelas kontrol 0,38 yang sama-sama terkategori sedang. Hal ini terjadi karena pada model pembelajaran langsung, guru lebih banyak memberikan penjelasan secara verbal. Kemudian guru pun memberikan penjelasan materi sel yang dikaitkan dengan kehidupan sehari-hari. Sehingga menjadi faktor skill 3 lebih tinggi dibanding kelas eksperimen. Namun, kelemahan yang terjadi di kelas eksperimen yaitu ketika melakukan kegiatan berkelompok hanya membahas pada satu topik bacaan materi sel perkelompok, menjadikan kemampuan peserta didik untuk mengevaluasi penggunaan dan penyalahgunaan informasi sainstifik meningkat namun skornya lebih rendah daripada kelas kontrol.

Pada skill 4 yang mengukur keterampilan memahami desain penelitian dan bagaimana dampaknya terhadap penemuan saintifik di kelas eksperimen mendapatkan skor $\mathrm{N}$-gain 
Quagga: Jurnal Pendidikan dan Biologi

Volume 12, Nomor 1, Januari 2020, pp.69-75
p-ISSN 1907-3089, e-ISSN2651-5869

https://doi.org/10.25134/quagga.v12i1.2123 yang terkategori sedang dan lebih tinggi dibandingkan pada kelas kontrol. Peningkatan tersebut terjadi karena dengan kegiatan membaca peserta didik terpahamkan akan kegiatan-kegiatan ilmiah. Kemudian dari sumber bacaan yang rata-rata didapatkan dari internet memberikan pemahaman peserta didik terhadap elemen-elemen penelitian.

Dari hasil yang didapatkan di atas, model RQA memiliki beberapa kelebihan dan kelemahan. Kelebihan dari model RQA, yaitu dapat meningkatkan minat baca dan kemampuan membaca peserta didik, meningkatkan rasa ingin tahu dan keaktifan belajar, mengingkatkan keterampilan berpikir kritis dan juga keterampilan literasi sains khususnya pada keterampilan mengevalusi penggunaan dan penyalahgunaan informasi saintifik, dan memahami desain penelitian dan bagaimana dampaknya terhadap penemuan saintifik. Sedangkan kelemahan dari model RQA pada penelitian ini yaitu tidak adanya bahan ajar yang sesuai yang sesuai dengan literasi sains.

Berdasarkan penjelasan tersebut, kelas eksperimen dan kelas kontrol sama-sama mengalami peningkatan, namun secara signifikan kelas eksperimen jauh lebih baik daripada kelas kontrol. Maka dapat disimpulkan bahwa penggunaan model RQA memiliki pengaruh yang baik terhadap peningkatan keterampilan literasi sains peserta didik.

\section{SIMPULAN}

Pada penelitian ini dapat disimpulkan bahwa model pembelajaran reading, questioning, and answering (RQA) dapat berpengaruh terhadap keterampilan literasi sains peserta didik pada materi sel. Khususnya pada dua skill dalam literasi sains, yaitu skill yang mengukur keterampilan mengevaluasi penggunaan dan penyalahgunaan informasi saintifik dan keterampilan dalam memahami elemen desain penelitian dan bagaimana dampaknya terhadap penemuan saintifik.

\section{UCAPAN TERIMA KASIH}

Penelitian ini selesai dengan bik berkat bantuan berbagai pihak. Penulis mengucapkan terima kasih untuk Dosen Pendidikan Biologi FKIP Universitas Siliwangi untuk bimbingan dan arahan selama penelitian.

\section{REFERENSI}

Akmaliya, N. I., \& Hapsari, A. I. (2016). Model Pembelajaran Reading, Questioning, and Answering (RQA) untuk Meningkatkan Hasil Belajar Siswa. Jurnal Biologi Dan Pembelajaran Biologi, 1(1), 69-80.

Bahri, A. (2016). Strategi Pembelajaran Reading Questioning and Answering (RQA) pada Perkuliahan Fisiologi Hewan untuk Meningkatkan Hasil Belajar Kognitif Mahasiswa. Jurnal Bionature.

Corebima, A. D., Hariyadi, S., \& Zubaidah, S. (2018). Contribution of Mind Mapping , Summarizing, and Questioning in the RQA Learning Model to Genetic Learning Outcomes. 15(1), 80-88. https://doi.org/10.12973/tused.10222a

Gormally, C., Brickman, P., \& Lut, M. (2012). Developing a test of scientific literacy skills (TOSLS): Measuring undergraduates' evaluation of scientific information and arguments. CBE Life Sciences Education. https://doi.org/10.1187/cbe.12-03-0026

Haerullah, A. (2013). Pengaruh Penerapan Model Reading, Questioning, and Answering (RQA) terhadap Pengetahuan Metakognitif Siswa Kelas XI IPA SMA Negeri 2 Kota Ternate. Jurnal Bioedukasi, 2, 180-184. https://doi.org/2301-4678

Holbrook, J., \& Rannikmae, M. (2009). The Meaning of Scientific Literacy. International Journal of Environmental \& Science Education, 4(3), 275-288. https://doi.org/10.1007/s00103-006$0011-y$

Liu, X. (2009). Beyond Science Literacy: Science and the Public. International Jurnal of Envoronmental \& Science Education, 4(3), 301-311.

Maknun, D. (2014). Penerapan Pembelajaran Kontekstual untuk Meningkatkan Literasi Sains dan Kualitas Argumen 
Siswa Pondok Pesantren Daarul Uluum PUI Majalengka pada Diskusi Sosiosaintifik IPA. Jurnal Tarbiyah, 21(1), 119-148.

Maulida, F., Yusrizal, \& Melvina. (2017). Penerapan Strategi Pembelajaran Reading Questioning and Answering (RQA) untuk Meningkatkan Hasil Belajar Siswa. Jurnal Ilmiah Mahasiswa (JIM) Pendidikan Fisika, 2(2016), 77-86.

Mulyadi, Adlim, \& Djufri. (2014a). Memberdayakan Kemampuan Berpikir Mahasiswa melalui Model Pembelajaran Reading, Questioning, and Answering (RQA). Jurnal Biotik, 2(1), 33-37.

Mulyadi, Adlim, \& Djufri. (2014b). Memberdayakan Kemampuan Berpikir Mahasiswa Melalui Model Pembelajaran Reading, Questioning, and Answering (RQA). Jurnal Biotik, 2(1), 33-37.

OECD. (2012). PISA 2012 Results in Focus. Programme for International Student Assessment, 1-44. https://doi.org/10.1787/9789264208070 -en

Purwanto, A. (2018). Pengaruh Model Reading, Questioning, and Answering (RQA) terhadap Keterampilan Berpikir Kritis Siswa Kelas XI IPA SMA PGRI 6 Banjarmasin pada Konsep Sistem Koordinasi Manusia. Jurnal Pendidikan Hayati, 4(1), 44-52.

Saptono, S., Rustaman, N. ., Saefudin, \& Widodo, A. (2013). Model Integrasi Atribut Asesmen Formatif (IAAF) dalam Pembelajaran Biologi Sel untuk Mengembangkan Kemampuan Penalaran dan Berpikir Analitik Mahasiswa Calon Guru. Jurnal Pendidikan IPA Indonesia, 2(1), 31-40.
Sudin, Duda, H. J., \& Supiandi, M. I. (2018). Pengaruh Model Reading Questioning Answering terhadap Kemampuan Berpikir Kritis Siswa pada Pokok Bahasan Sistem Pernapasan Manusia. JPBIO (Jurnal Pendidikan Biologi), $3(1), 1-8$.

Wakhidah, N. (2012). Keterampilan Membaca dan Menulis dalam Meningkatkan Berpikir Kritis dan Literasi Sains. Seminar Nasional Prodi Pendidikan Sains, 71-84.

Yaumi, Wisanti, \& Admoko, S. (2017). Penerapan Perangkat Model Discovery Learning Pada Materi Pemanasan Global untuk Melatihkan Kemampuan Literasi Sains Siswa SMP Kelas VII Yaumi Mahasiswa Program Studi Pendidikan Sains FMIPA UNESA, email: yaumi.sains15@gmail.com Wisanti Dosen Jurusan Bio. E-Journal Pensa, 05(01), 38-45. 